\title{
SOCIAL MEDIA: AN IMPEDIMENT OR INSPIRATION TO IMPLEMENTATION OF DIGITAL LITERACY PROGRAMME IN KISII COUNTY, KENYA
}

Teresa K. ABUYA*, Department of Computing Sciences, Kisii University, Kenya

Omosa E. MOCHAMA, Department of Physics, Kisii University, Kenya Edwin O. MAKWORO, Department of Engineering, Kisii University, Kenya

Přijato: 21. 12. 2019 / Akceptováno: 1. 9. 2020

Typ článku: Teoretická studie

DOI: $10.5507 /$ jtie.2020.017

Abstract: Information Communication Technology (ICT) has revolutionized the way different sectors in developed and developing countries operate. They have pervaded modern societies as tools for transforming education systems, supporting economic development through the creation of new products and services, providing access to information and expertise to support improvements in agriculture, health and education, and connecting communities, teachers and students. Education sector in many countries have embraced ICT in research, teaching and learning. This has given rise to innovative learning pathways suited for different learners' situations. In initial adoption of ICT, 1higher education institutions were the first beneficiaries but in recent times, lower learning institutions like primary schools have also embraced the same. In Kenya, ICT Integration in Primary Education is one of the key flagship programmes borne out of government of Kenya's vision to make sure every pupil is prepared for today's digital world and to realize this, Digital Literacy Programme (DLP) was introduced for lower Primary schools in Kenya, particularly Class One Pupils. This study looks at the perceived ease of use and usefulness of social media by teachers of primary schools in Kisii County of Kenya and implementation success level of the Digital Learning Programme (DLP) by these teachers. Assessed was the teachers' view of technological complexity of social networking (SN) media. Survey research design was applied in the study. Random, proportionate and purposive sampling methods were used to select 250 primary schools and 276 teachers. Teachers of lower primary school segment of the Kenyan education system were surveyed using self-administered questionnaires on the frequency and ease of use of technology for Social Networking media such as Facebook, WhatsApp and Twitter and asked about their intensity of use. The results obtained showed that WhatsApp and Facebook use have a significantly increased impact on teachers' collaboration and engagement. Further, that perceived ease of use is 
a predictor of perceived usefulness and both of these have impact on social media use of teacher for educational purposes. Teachers accessed internet easily with the use of mobile smart phones which allows them to converse and interact with each other, to create, edit and share new forms of textual, visual and audio content. Those who use it frequently have made great attempts to implement Digital Learning Programme with ease whereby teachers use Teacher Digital Device (TDD) and learners use Learning Digital Device (LDD). This paper concludes that social media can be used as an educational tool to help teachers to collaborate and engage and recommends that the ministry of education embrace the uses of social media for teaching and learning.

Key words: social media, Learner Digital Device (LDD), Digital learning Programme (DLP).

\section{SOCIÁLNÍ MÉDIA: PŘEKÁŽKA NEBO INSPIRACE K PROVÁDĚNÍ PROGRAMU DIGITÁLNÍ GRAMOTNOSTI V OKRESU KISII V KENI}

Abstrakt: Informační a komunikační technologie (IKT) způsobily revoluci ve způsobu fungování různých odvětví v rozvinutých i rozvojových zemích. Pronikly do moderních společností jako nástroje pro transformaci vzdělávacích systémů i podpory hospodářského rozvoje. Vytvářením nových produktů a služeb a poskytnutím přístupu $\mathrm{k}$ informacím a odborným znalostem umožnily pokrok $\mathrm{v}$ zemědělství, zdravotnictví a vzdělávání a propojení komunit, učitelů a studentů. Odvětví vzdělávání v mnoha zemích plně začlenilo IKT do oblasti výzkumu, výuky i učení, což umožnilo rozvoj inovativních způsobů učení vhodných pro různé situace, ve kterých se žák nachází. V počáteční fázi začleňování IKT do výuky měli z tohoto procesu prospěch zejména vysokoškolské instituce, nicméně v poslední době z něj profitují i instituce nižšího vzdělávání, včetně základních škol. V Keni je proces začleňování ICT do výuky na základních školách jedním ze stěžejních programů vycházejících z vize keňské vlády zajistit, aby byl každý jejich žák připraven na dnešní digitální svět. Za tímto účelem byl na prvním stupni keňských základních škol, a zejména v prvních třídách, zaveden Program digitální gramotnosti (DLP). Tato studie se zabývá předpokládanou jednoduchostí použití a užitečností sociálních médií z pohledu učitelů základních škol v okrese Kisii v Keni a mírou úspěšnosti provádění programu digitálního učení (DLP) těmito učiteli. Posuzován byl názor učitelů na technologickou složitost sociálních médií, a to metodou výzkumného šetření. Metodou náhodného, přiměřeného a účinného výběru byl vybrán vzorek 250 základních škol a 276 učitelů. Učitelům nižšího stupně základních škol v rámci keňského 
vzdělávacího systému byly pomocí SAQ dotazníků (vyplňovaných respondentem) pokládány otázky ohledně toho, jak často, s jakou lehkostí a s jakou intenzitou používají technologie sociálních médií, jako je Facebook, WhatsApp a Twitter. Získané výsledky ukázaly, že používání aplikací WhatsApp a Facebook výrazně ovlivňuje spolupráci a zapojení učitelů. Předpokládaná jednoduchost použití je zároveň prediktorem předpokládané užitečnosti a obě tyto skutečnosti ovlivňují míru, do jaké učitelé sociální média využívají pro vzdělávací účely. Snadný přístup učitelů k internetu pomocí chytrých mobilních telefonů jim umožnil spolu konverzovat a vzájemně komunikovat, vytvářet, upravovat a sdílet nové formy textového, vizuálního a zvukového obsahu. Ti, kteří internet používali často, se následně ve velké míře zapojili do snahy o zavedení programu digitálního učení, s využitím nástroje pro učitele Teacher Digital Device (TDD) a digitálního výukového nástroje (LDD) pro žáky. Tento dokument dochází k závěru, že sociální média lze využít jako vzdělávací nástroj, který učitelům pomáhá spolupracovat a zapojit se, a doporučuje, aby myšlenku využití sociálních médií pro výuku a učení přijalo za svou i ministerstvo školství.

Klíčová slova: sociální média, digitální výukový nástroj (LDD), digitální učení.

*Autor pro korespondenci: tkwambokaa@gmail.com 


\section{Introduction}

Kenya's vision 2030 programme recognizes the value of Information Communication Technology (ICT) in its growth to a rapidly industrializing economy by the year 2030 . One of the vision 2030 flagship projects for education and training is to establish a computer supply programme that will equip students with modern technological skills. It is with this in mind that the Kenya government re-launched the Digital Learning Programme (DLP) for all primary schools. DLP is basically an E-learning programme aimed at effective delivery of education to the Kenyan child in primary schools. DLP which is also referred to as the laptop programme aims at aligning integration of ICT into teaching and learning. Information Communication Technology (ICTs) have an unmistakable part in enhancing nature of instruction and learning (Fathima, 2013) and in changing the worldwide status of classroom teaching (Sasidharakurup et.al, 2015). It is considered that ICT is a versatile source of scientific information, theoretical information and offers a viable means for supporting learning authentically in science (Awad, 2014).However, in developing nations including Kenya, though computers and ICTs are becoming increasingly available in the educational institutions, including the primary schools they are not being used in actual teaching. Instead, they are mainly applied in facilitating clerical activities, processing of examinations, timetabling and keeping of school records. Zgheib(2013), found that there were several challenges why virtual laboratories are not used in Lebanon in curriculum instruction. They range from the lack or inadequacy of hardware and software to lack of knowledge, skills and attitudes toward the infusion of technology in education. They have not been infused in curriculum delivery (Kirimi, 2014). Chesitit (2015), in the West Pokot County, Kenya study strongly recommended to the Ministry of Education, Science and Technology (MOEST) to integrate ICT skills with other teaching strategies during the curriculum to be integrated with the other instructional approaches in the secondary school curriculum and digitize curriculum content. Bhattacharya and Sharma (2007) described e-learning as the delivery of course content through electronic means which include computer-based learning, online learning and distance education. E-learning is the integration of modern technology into the classrooms which can sometimes include learning that is completely independent of mediation (Voogt \& Knezek, 2008). The biggest domains of the users of e-learning are schools, colleges and universities which have paid special attention to e-learning in order to expedite the learning procedures (Olatokun \& Opesade, 2008). To successfully implement e-Learning, learning institutions should first assess their readiness to integrate the technology (Saekow \& Samson, 2011).

3-Dimensional interfaces are utilized to submerge a user into an interactive situation. This kind of interface makes it simpler to comprehend information by utilizing perception, sight, and possibly sound to present information. Bergerud (2008) posts that two phenomena which are of great use lately for supplementing customary techniques are; interactive three-dimensional (i3D) and simulation based learning (SBL). This kind of learning is imperative to display substance to students through representation. A major instance being that, instead of the trainees doing real hands-on procedures they can use virtual learning, offering them more safety. This utilization can encourage more students to get interested in self-studies, therefore leading to learners getting content outside the usual classroom thus resulting in a flipped classroom and application as well as 
consolidation of the main points happens amid class time (Fitzgerald \& Li, 2015; Bowen, 2012; Esson, 2016).

Efficiency in the classroom require learners to access information faster and easier and computers and their associated software can deliver instructional programs and information fast, covering virtually any area of the curriculum and geared to any age or ability level (Westwood, 2008). Chen et.al,(2004) notes that E-learning is embraced by almost every educational institution as a positive step towards improving performance, learning, speed, flexibility, versatility, interactivity and ultimately enabling learners to be more autonomous. Consequently, educators are increasingly aware of the potential and practicalities of using computer assisted learning in the primary classroom and in many circumstances have adopted it as just another pedagogy (Mioduser et.al, 2000). There is no doubt that the introduction of E-learning to primary schools has been one of the most significant developments for teachers and students, yet it seems to have had little effect on the way teachers teach (Kennewell et.al, 2007).

All learning experiences are unproven until they have been thoroughly evaluated well before they could be judged as reliable, appropriate or even adequate for children (Trindade, et.al, 2000). In order to benefit from e-learning it is necessary to consider upfront analysis to assess the readiness of prospective e-learning implementation (Aydın \& Tasci, 2005). It is therefore prudent to assess the e-learning readiness of primary schools implementing DLP in Kenya. Readiness is defined as being "prepared mentally or physically for some experience or action" (Webster's New Collegiate Dictionary). Borotis \& Poulymenakou (2004) define e-learning readiness as "the mental or physical preparedness of an organization for some e-learning experience or action".

This study looks at the perceived ease of use and usefulness of social media by teachers of primary schools in Kisii County of Kenya and implementation success level of the Digital Learning Programme (DLP) by these teachers. Assessed was the teachers' view of technological complexity of social networking (SN) media. Survey research design was applied in the study. Random, proportionate and purposive sampling methods were used to select 250 primary schools and 276 teachers. The Teacher Digital Devices(TDDs) and Learning Digital Devices(LDDs) were evaluated to ascertain ease of use by lower primary teachers.

\section{Review of Related Study}

Several studies have been conducted to explore the role of social media on teachinglearning. Joanne \& Michael (2011), conducted a study about student perspectives on learning with cell phones, smartphones \& social media mobile computing devices in higher education.They explored the teaching and learning when mobile computing devices, such as cell phones and smartphones, were implemented in higher education. They presented a portion of the findings on the perception of students using mobile computing devices and what could be the role of social media in education. Nazan et.al,(2009) conducted research on the use of the internet for educational purposes focusing on the use of internet in primary education. They found out that information spreads fast through social media and can be useful in educational institutions. A Rich source of information could be accessed on the internet may contribute a great factor to primary education. They also investigated the role of the internet to college students in Korea. They conducted open-ended survey online to 
some Korean university students. They used the word-frequency analysis and semantic mapping to monitor the use of the internet by the college students. Anticipated results would empower educators and policymakers to design and to plan e-learning programs for college students. Teachers and curriculum development in technology education in New Zealand, England, Wales and many other countries have reflected on the perceptions of teachers (Parkinson \& Hope, 2009). Essentially, influences of past experiences, attitudes towards change, teacher involvement and preparedness to take risks have been major features for understanding teachers' perceptions towards technology education and its implementation. Curriculum change and consequently teaching and learning in technology have largely been influenced by competing ideologies which Parkinson (2009) described as subject subcultures. According to Parkinson, such subcultures represent contested but more-or-less consensus views about such things as the nature of the subject, the way it should be taught, the role of the teacher and what might be expected of the student. Implementation of a technology curriculum must take into account subjective realities of the teachers on the ground in determining curriculum and pre-service and in-service teacher training programmes including professional development. As perceptions directly influence classroom practices and subsequent learning in technological concepts and processes, positive views may help teachers to conceptualize teaching and learning that imparts thinking skills for students' active engagement in a technologically mediated sphere using E-Learning (Solomonidou \& Tassius,2007). Understanding teachers' cultures, beliefs and practices appears to be helpful in developing teachers' perceptions and their readiness to shift from a prescriptive paper based curriculum to Digital content curriculum. This aspect could be mitigated during curriculum change with teachers' active engagement in the review and implementation processes taking into consideration their experiences, existing beliefs and practices and most importantly the need to embrace ICT in teaching and learning. Education has been identified as one of the public sectors most influenced by technological developments (McCormick, 2004). The improvement of educational systems and increased educational attainment are primary to countries' preparation for global, technology-based changes in all sectors. In the West, the rationale for technology education was epitomized by economic, social and educational assumptions, but their technological advancement also influenced the nature of their technology education (Unwin, 2009). Many other countries, particularly those categorized as least developed countries, have maintained their imperial curriculum, as they have, over the past two decades, been preoccupied with democratization, poverty alleviation and other socio-economic problems (Stein et.al,2007). This is attributed to the state of technology education in least developed countries to political instability, resource constraints and lack of scholars with a shared understanding of technology.

Among the sub-Saharan African countries, the Republic of South Africa (RSA) and Botswana have incorporated technology education and design and technology respectively as learning areas in their curricula (Stevens, 2006). Botswana and RSA are classified by the World Bank (2007) as upper middle income economies with gross national income per capita between US\$3,706 and US\$11,455 which is much higher than other countries within the region. The two sub-Saharan nations are hence economic giants with a huge and more developed capacity for investment in education compared to other countries within the Southern African region and their position as such does influence knowledge and policy 
developments. In 2008, Mioduser asserted that an understanding of technology is vital in the modern world, and must be part of everyone's basic education.

In recent years, the worlds of online learning and computer-aided instruction have converged to some extent, morphing into what is often referred to as blended- or personalized-learning models. There are a number of interesting projects underway across the country, including pilots supported by the Gates Foundation's Next Generation Learning Challenge, and the emergence of charter networks with a goal to provide truly personalized learning for every student, such as Summit Public Schools in California and Washington(Brian,2016).

Lack of understanding of technological methods makes one more and more dependent on others in daily life, narrows employment possibilities and increases the danger that the potentially harmful effects of the unrestrained application of technology. The Digital Literacy Program kicked off at Kiambu Township Primary School in Kiambu County, Kenya in May, 2016 following the delivery and installation of 212 tablets, 2 teacher devices (laptops), a projector and a content access point (CAP) to benefit class one pupils and tutors at the school. The project is being implemented under the Government's digital literacy program, currently at the piloting stage. This study aims at establishing the current status of e-learning readiness of these primary schools. It aims to assess attitudes and perceptions of teachers during the training and mentoring period as the teachers attempt to implement the use of ICT in their teaching. It will consolidate their observations on what teachers view as difficulties and therefore impediments in their endeavor in integrating ICTs in their lessons. The study attempts to bring to the fore according to the teachers on what works and what doesn't, what motivates them in using or not using ICTs, what demotivates them and what needs to be improved if integration is to be done smoothly. It is expected that the findings of this paper will provide insights into training manuals for future training in ICT integration. The study will zero in on primary schools in Kisii County.

\subsection{Problem Statement}

There is little literature on the use of social media in instruction at the primary school level. Much literature that is available is in either the secondary segment of education, college or university. Before any technology can be utilized, it is imperative to establish that it will obtain that which it claims to. Therefore, this study was performed to evaluate the use of social media by the primary school teachers in Kisii County, Kenya in instruction related activities and its influence of the teachers in the use of ICT in instruction delivery of content.

The main objectives of this study were to find out the influence of social media usage by the teachers on the teaching-learning using Digital Learning Programme in Kisii County, Kenya and also understand the attitudes and perceptions of teachers implementing the use of teacher digital devices (TDD) in primary schools in Kisii County

\section{Methodology}

This section looks at research design, sampling, research instruments, their reliability and data analysis. The research design directs the research activities to ensure that valid conclusions are attained (Durrheim, 2009). A research design is described as a planned 
framework for action that serves as a connection between research questions and the execution or implementation of the research (Durrheim, 2009, Babbie \& Mouton, 2004). The study applied survey research design. Survey design was chosen because it was economical and has a rapid turn-around in data collection. It also has the advantage of identifying attributes of a large population from a small group of individuals (Babbie, 2008 $\&$ Fowler, 2002).

The population of the study consituted 710 primary school head teachers, 1,420 Grade One and Grade Two teachers and 71,000 Grade One and Grade Two pupils. The study sampled 250 schools randomly for inclusion in the study. Then the teacher(s) who teach the sampled schools were selected by use of proportionate sampling for inclusion in the study. This resulted in 310 Primary Class One and Two teachers.

Three research instruments were applied in this research; self-administered questionnaires, interview schedules and observation schedules. According to Mugenda and Mugenda (2003), a self-administered questionnaire is one in which respondents complete the questionnaires themselves. According to Babbie (2008), survey research can apply questionnaires or structured interviews for data collection. The self-administered questionnaires were applied in collecting data from teachers and head teachers while the interview schedules and observation schedules were used for pupils.

To establish the reliability of the research instruments a pilot-test was carried out in three primary schools in Nyamira County and the Cronbach's alpha was used to measure the internal consistency of the instruments. A Cronbach's alpha coefficient of 0.7 was deemed acceptable and any items falling below this was eliminated to improve the reliability.

\subsection{Data analysis}

The survey data was analysed qualitatively and quantitatively using descriptive statistics in SPSS version 22 and the main statistical tests that were used are chi-square, regression and correlation. The data collected by use of questionnaires was edited and coded. It was then analyzed using descriptive statistics in SPSS version 22 with chi-square, regression and correlation as the main statistical tests. Descriptive statistics involves tabulating, graphing and describing data. This simplifies data so that the general trend can be seen (Orodho 2003). Mugenda and Mugenda (2003) notes that the purpose of descriptive statistics is to enable the researcher to meaningfully describe a distribution of scores or measurements using a few indices or statistics. Data collected from the interview sessions was edited for clarity and relevance. Thematic analysis was used to derive codes from key quotations insights and interpretations and then compared for consistencies and differences.

\section{Results Discussion}

\subsection{Profile of the Respondents}

A total of 310 Lower primary school teachers were sampled for the study. A questionnaire was administered to them to elicit responses that would guide the researchers get to answer the research questions that they had formulated. All of them participated while only 45 participated in the survey. The table below shows percentage for LDDs Implementation in lower primary schools. 


\section{Percentage of LDDs Teacher Implementation}

Teachers who never used LDDs
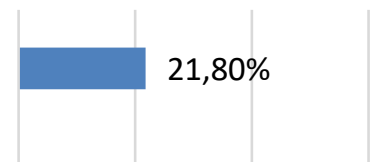

Teachers who used LDDs

$78,20 \%$

\section{$0,00 \% \quad 20,00 \% \quad 40,00 \% \quad 60,00 \% \quad 80,00 \% \quad 100,00 \%$}

\section{Image no. 1: Percentage of Lower Primary LDDs implementation}

Figure 2.0 below has a pie chart showing teachers' highest level of education. The majority of the respondents with $78 \%$ had a P1 (Certificate course in Education), while others who are teaching possess other P1 with Bachelors Degree at 22\%. Most of the respondents are government employees.

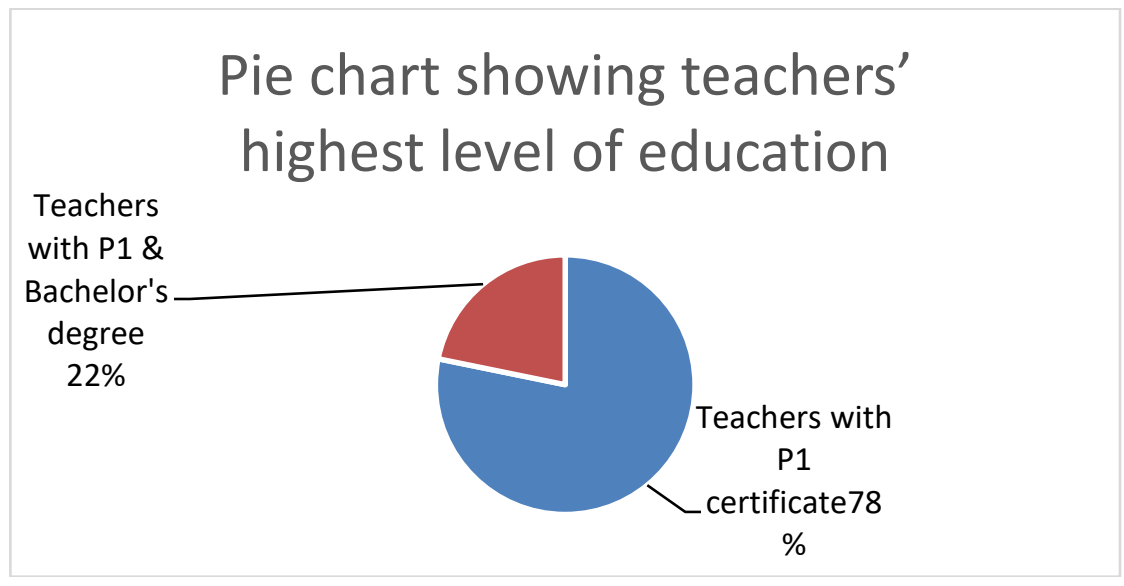

Image no. 1: Pie chart showing teachers' highest level of education

They teach all the subjects in the curriculum at that level. The number of years of teaching experience ranges between two and thirty three and their ages between 28 and 51 years. It is evident that the teachers rarely use desktop computers or laptops or tablets, once in a while they use word processing, spreadsheets and in minima occasions do they use powerpoint presentation in their instruction. This can be evidenced from the fact that on a 
scale of 1 to 5 they have means of $3.46,2.55$ and 2.51 respectively as depicted in table 1 below.

\begin{tabular}{|l|l|l|l|l|}
\hline Item Used & Minimum & Maximum & Mean & $\begin{array}{l}\text { Standard } \\
\text { Deviation }\end{array}$ \\
\hline Word processing & 1 & 5 & 3.46 & 0.8 \\
\hline Spreadsheets & 1 & 5 & 2.55 & 0.78 \\
\hline Powerpoint presentation & 1 & 5 & 2.51 & 0.79 \\
\hline
\end{tabular}

Table no 1: How teachers utilize various applications

With the huge standard deviations involved here, it means that the usage is quite spread, with some users seldom using while others would be using the software a lot. Basically with these means the primary school teachers hardly use the technologies for teaching and learning purposes.

\subsection{Perception of Teachers in the Usefulness of Social Media Classroom}

The result is divided into two, the first one is the perception of teachers in the usefulness of social media in academic usage. The second one is the usefulness of social media in non-academic usage. The majority of the respondents agreed that social media is useful in academic-related activities. Social media is much useful in sharing of information and teacher-teacher interactions. The results indicates that (78.2\%) of teachers have used Learners Digital Devices (LDDs) while (21.80\%) of teachers have not used LDDs for curriculum delivery. It also indicates that $(58.3 \%)$ of teachers use TDDs for content delivery and $(41.7 \%)$ use smartphones to enhance content delivery on operations of TDDs. These are shown in figure 3.0 and figure 4.0 below respectively.

\section{Usage of LDDs} by Teachers

21,80 $\%$

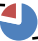
78,20 $\%$

- Teachers who used LDDs

- Teachers who never used LDDs

Image 3: Usage of LDDS by teachers

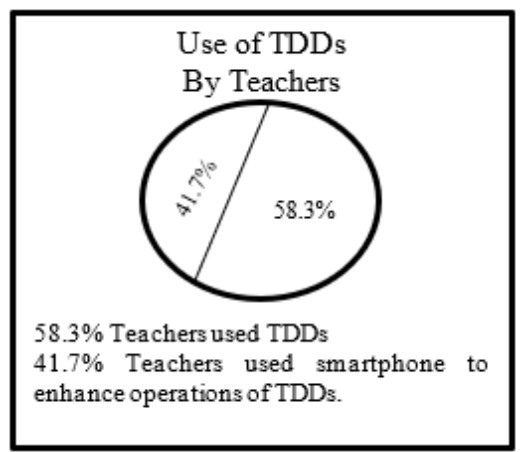

Image 4: Usage of TDDs by teachers

The above figure evidently show that teachers are not using the TDDs more often. However, they are using the LDDs with the learners. This could be indicative of either a low attitude towards the TDDs usage (or even the whole programme) or inadequacy in the computer skills or both. 


\subsection{Usage and Acceptability}

\begin{tabular}{|l|l|l|}
\hline Online Account & Used & Never Used \\
\hline WhatsApp & $76 \%$ & $24 \%$ \\
\hline Facebook & $56.9 \%$ & $43.1 \%$ \\
\hline Google search & $52.3 \%$ & $47.7 \%$ \\
\hline Twitter & $23.4 \%$ & $76.4 \%$ \\
\hline Others & $12.2 \%$ & $87.8 \%$ \\
\hline
\end{tabular}

Table no 2: $\quad$ Utilization of various applications by teachers

Most of the respondents are having their WhatsApp account garnering $76 \%, 2 \mathrm{nd}$ is Facebook having $56.9 \%$ and $52.3 \%$ for Google search. Twitter is to a small extent used by $23.4 \%$ of the teachers. WhatsApp is most often used social media among the respondents. On how the social media was accessed, using a smartphone had $78.7 \%$ of them have using it for WhatsApp in the past one month, 63.6 percent used it for facebooking and 34.9\% for google search. The respondents use their accounts for 1 to 3 hours stood at $32.3 \%, 23.4 \%$ of respondents using their social media accounts for 3 to 5 hours and the other $24.3 \%$ for less than an hour.

Their main purpose of having an account is mainly for social networking having $88.9 \%$, news update for $80 \%$ and $48.9 \%$ for video streaming and downloading. $58.4 \%$ use social media accounts for education-related activities. And the remaining percentage (sole respondent) is not using social media in education-related activities for it does not suite the respondent's needs in education-related activities.

Based on the total number of hours used in social media, $43.2 \%$ respondents use 26 to $50 \%$ of their total time spent in social media, while $36.4 \%$ use less than $25 \%$ of total time spent.

The respondents were asked on what educational purpose they use the social media. Of all the ones using social media for professional networking, 52.3\% use it with other educators. An appreciable number of the respondents use social media for the educational purpose. The respondents were also asked what the importance of social media is in today's education. Most respondents agreed that social media "facilitate communication" and "builds connection" with a total of $67.3 \%$ for both importance. Lastly, $93.2 \%$ of the total respondents are facing low internet connectivity.

\section{Conclusion and Recommendation}

Based on the result, the researchers concluded that social media could play a vital role in implementation of DLP in Kisii County and Kenya at large. The result of this study shows that social media could help teachers maximize the use of DLP. It was noted that DLP in Kisii County is still lagging behind in terms implementation. This is attributed to negative attitudes on the part of teachers and technophobia as they perceive technology as very difficult to understand. There is need for all schools especially in the rural to have adequate power supply because these gadgets cannot operate without electricity. Lastly 
parents should encourage their children to embrace new technologies which is a major challenge in most rural areas where a higher population of the pupils resides in.

\section{Acknowledgement}

Appreciation goes to the National Research Fund for providing us funds to conduct this research.

\section{References}

Anderson, T., \& Dron, J. (2011). Three generations of distance education pedagogy. The International Review of Research in Open and Distributed Learning, 12(3), 80-97.

Aydın, C. H., \& Tasci, D. (2005). Measuring Readiness for e-Learning: Reflections from an Emerging Country. Educational Technology \& Society, 8(4), 244-257.

Awad, B. (2014). Empowerment of teaching and learning chemistry through information and communication technologies. AJCE, 2014, 4(3), Special Issue (Part II)

Babbie, E. (2008). The basics of social research. $4^{\text {th }}$ ed. Belmont, Califonia: Thompson Wadsworth.

Babbie, E. \& Mouton, J. (2004). The practice of social research. Cape Town: Oxford University Press.

Bergerud, M. (2008). Interactive 3D (i3D) and Simulation-Based Learning (SBL) Revolutionize Learning, community college week, 10.

Bhattacharya, I., \& Sharma, K. (2007). India in the knowledge economy -an electronic paradigm. International Journal of Educational Management, 21(6), 543 -568.

Borotis, S. and Poulymenakou, A. (2004). E-Learning Readiness Components: Key Issues to Consider Before Adopting e-Learning Interventions. Retrieved on Nov. 2, 2005 from http://www.eltrun.gr/papers/e LReadiness_ELEARN2004.pd

Bowen, J. A. (2012). Teaching Naked: How Moving Technology Out of Your CollegeClassroom Will Improve Student Learning, Jossey-Bass, San Francisco, CA.

Brian A. Jacob (2016), The opportunities and challenges of digital learning (A report).Retrieved from Bookings May,2016

Broadley, T. (2012). Enhancing Professional Learning for Rural Educators by Rethinking Connectedness. Australian and International Journal of Rural Education, 22(1), 85 -105.

Chesitit, B. C. (2015). Impact of ICT Integration on Mathematics Performance in Kenya: A Case Study of Public Secondary Schools in West Pokot County. University of Nairobi, Education, Nairobi.

Durrheim, K. (2009). Research design. In Terre Blanche, M, Durrheim, K \& Painter, D. (Eds), Research in practice: applied methods for the social sciences (pp 30-40). Cape Town: University of Cape Town Press.

Esson, J. M. (2016). 'Flipping general and analytical chemistry at a primarily undergraduate institution', in The Flipped Classroom Volume 2: Results from Practice, (Eds.) Muzyka, J., \& Luker, C. pp. 107-125. ACS Symposium Series; American Chemical Society: Washington, DC

Fathima, S. (2013). Challenges of ICT in Teaching Learning Process. International Journal of Engineering Science, 2, 51- 54. 
Fitzgerald, N., \& Li, L. (2015). 'Using presentation software to flip an undergraduate analytical chemistry course', Journal of Chemical Education, vol. 92, no. 9, pp.1559-1563. Fowler, F. J. (2002). Survey Research Methods ( $3^{\text {rd }}$ ed.). Thousand Oaks, CA: SAGE. Hew, K. F. (2011). Students' and teachers' use of Facebook. Computers in human behavior, 27(2), 662-676.

Kaplan, A. M., \& Haenlein, M. (2011). The early bird catches the news: Nine things you should know about microblogging. Business horizons, 54(2), 105-113.

Kennewell, S; Tanner, H; Jones, S \& Beauchamp, G. (2007). Analysing the use of interactive technology to implement interactive teaching. Journal of Computer Assisted Learning. Retrieved April, 22 from ERIC database.

Kirimi, K., J. (2014). Impact of Information Communication Technology on Education in Kenya. Journal of Educational and Social Research, 4 (1).

McCormick, R. (2004). Issues of learning and knowledge in technology education.

International Journal of Technology and Design Education, 14(1), 21-44.

Mioduser, D., \& Betzer, N. (2008). The contribution of project-based learning to high -achievers' acquisition of technological knowledge and skills. International Journal of Technology and Design Education, 18(1), 59-77.

Mioduser, D, Nachmias, R, Lahav, O \& Oren, A. (2000). Web-based learning environments: current pedagogical and technological state. Journal of Research on Computing in Education, 33(1), 55-76. Retrieved May 7, 2008 from EBSCO database.

Mugenda, M. O. and Mugenda, G.A. (2003). Research Methods: Quantitative and Qualitative Approaches. Nairobi: African Centre for Technology Studies.

Olatokun, W. M., \& Opesade, O. A. (2008). An e-readiness assessment of Nigeria's Premier University (Part 1*). International Journal of Education and Development using Information and Communication Technology (IJEDICT), 4 (2), 16-46.

Parkinson, E., \& Hope, G. (2009). The conceptual learning in and through technology. Innovations in Education and Teaching International. Retrieved May 15, 2008 from ERIC database.

Saekow, A., \& Samson, D. (2011). E-learning Readiness of Thailand's Universities Comparing to the USA's Cases. International Journal of e-Education, e-Business, $e$ Management and e-Learning, 1(2), 126 -131.

Sasidharakurup, H., Radhamani, R., Kumar, D., Nizar, N., Achuthan, K., and Diwakar, S. (2015). Using Virtual Laboratories as Interactive Textbooks: Studies on Blended Learning in Biotechnology Classrooms. EAI Endorsed Trans. E Learning 2, e4. doi: 10.4108/el.2.6.e4.

Stein, S., Ginns, I., \& McDonald, C. (2007). Teachers learning about technology and technology education: Insights from a professional development experience.

International Journal of Technology and Design Education, 17(2), 179-195.

Solomonidou, C., \& Tassios, A. (2007). A phenomenographic study of Greek primary school students' representations concerning technology in daily life. International Journal of Technology and Design Education, 17(2), 113-229. doi: 10.1007/s10798-006-0007-9 Stevens, A. (2006). Technology teacher education in South Africa. In M. J. de Vries \& I. Mottier (Eds.), International handbook of technology education: reviewing the past twenty years (pp. 515-532). Rotterdam, Netherlands: Sense. 
Trindade, A., Carmo, H. \& Bidarra, J. (2000). Current developments and best practise in open learning and distance education. Retrieved July 12, 2007 from www.icaap.org.

Unwin, T. (2009). The technologies: identifying appropriate solutions for development needs. In T. Unwin (Ed.), ICT4D: Information and Communication Technology for Development: Cambridge University Press.

Voogt, J., \& Knezek, G. (2008). International Handbook of Information Technology in Primary and Secondary Education. New York: Springer.

Westwood, P. (2008). A parent's guide to learning difficulties. Melbourne: Australian Council for Education

Zgheib, R. S. (2013). Organizational support of technology integration in one school in Lebanon (Doctoral dissertation). Retrieved from ProQuest Dissertations and Theses database. (UMI No. 3596298) 